\title{
An Analysis on Job Satisfaction of Employees in Govt. Banks: A Study on Janata Bank Limited
}

\author{
Md. Siddikur Rahman ${ }^{1}$, Md Nazmul Haq ${ }^{2}$, Mohammad Maksudul Karim ${ }^{3}$ \\ ${ }^{1}$ Lecturer, Department of Management Studies, Comilla University, Comilla Bangladesh ${ }^{2}$ \\ Student of MPA in School of Public Affairs, Zijingang Campus, Zhejiang University, Hangzhou, PRC \\ ${ }^{3}$ Assistant Professor, Department of Management Studies, Comilla University, Comilla, Bangladesh
}

\begin{abstract}
Jobs in banking sectors are very attractive to the people of Bangladesh because of its attractive working environment, handsome salary and so on. But all the employees are not still satisfied with their jobs due to some noticeable factors especially in govt. banks. Job satisfaction is the bunch of internal and external factors stimulating desires and energy in people to be continually interested in and committed to a job, role, or subject and to exert persistent efforts in gaining goals. The main objective of the study is to analyse and reveal the satisfaction level among the employees of Govt. Banks. Some findings of the study are high workload and working stress comparing with compensation package, good loan facilities but average level of allowance and other incentives for the employees, moderate satisfactory leave facilities, good opportunity for the employee training, moderate promotion system and so forth. Job satisfaction puts human resources into action and improves level of efficiency of employees. It leads to the stability of workforce that is very important from the point of view of reputation and goodwill of the company. So, it is recommended that necessary steps should be taken to remove the dissatisfactory factors regarding promotion system, allowance and other incentives, workload and working stress and so on.
\end{abstract}

Key Words: Job Satisfaction, Compensation, Workload and Stress, Working Conditions, Financial Rewards

\section{Introduction}

Bangladesh is a developing country with an under developed banking system, particularly in terms of the services and customer care provided by the government banks. At present, the private banks are attempting to imitate the banking structure of the more developed countries, but this attempt is often failed by politically motivated government policies executed by the central bank of Bangladesh, Bangladesh Bank. In modern business world, service-oriented companies significantly play roles to shape the economic structure of world economy. Especially depository institutions such as commercial banks are the major service-oriented businesses dealing with customers to serve their needs at the best level. Now-a-days to attain the specific goal companies strive to build a sustainable and profitable relationship with their employees. A sustainable and profitable relationship with their employees is possible by achieving their job satisfaction. It is the bunch of "internal and external factors that stimulate desire and energy in people to be continually interested in and committed to a job, role, or subject and to exert persistent efforts in gaining goals". The performance of motivated employees is high, which results into: increased productivity and reduced cost of operations etc. Motivated people are not resistant to the changes taken into the organizations. As long as the needs of employees are met through attractive rewards, promotional opportunities etc., employees begin to take more interest in their company. They begin to think that there is no difference between the interests of the enterprise and their interests.

\subsection{Company Profile}

Janata Bank Limited is a state-owned and second largest commercial bank in Bangladeshestablished in 1971. It has an authorized capital of BDT. 20,000.00 million, paid up capital of BDT. 19140.00 million, reserve of BDT. 17976.20 million. The Bank has a total asset of Tk. 586082.98 million as on 31st December 2013.

There are 906 branches of Janata Bank Limited in home and abroad. Among them 443 branches are situated in urban areas including four foreign branches and 408 branches are in rural areas. And all foreign branches are situated in United Arab Emirates. The Bank employs around 14244 persons. The corporate head office is located at Dhaka with 35 (thirty five) districts. As a part the conscious development of existing Human Resources, Janata Bank through its three training institutes imparts training to officers and staffs. It has already been computerized most of the branches; non-stop services introduced in 88 branches.

The Board of Directors is composed of 13 (Twelve) members headed by a Chairman. The Directors arerepresentatives from both public and private sectors. The Bank is headed by the Managing Director (Chief Executive), who is a reputed banker. 


\subsection{Objectives of the Study}

The main objective of the study is to analyse and reveal the satisfaction level among the employees of Janata Bank. In addition, some specific objectives are as follows:

1. To gain deep knowledge about employees job Satisfaction level in different positions of Janata bank;

2. To know the motivational factors affecting employees job Satisfaction of the specific bank;

3. To achieve deep knowledge about employees job dissatisfaction in performing jobs in Janata bank.

\subsection{Methodology of the Study}

This study is basically conducted based on purposive sampling or judgemental sampling. The population of this study are all the branches of Janata bank. From the population total eight (8) branches are taken as a sample size. Total sixty (60) respondents were interviewed at 8 branches. To conduct the study both primary and secondary data sources are used.

\section{Primary Data Sources:}

Primary data has been collected through direct survey with a structured questionnaire.

\section{Secondary Data Sources:}

Most of the information required for this study were collected from secondary sources. It includes different manuals of JBL, different circulars of JBL, institution booklet \& annual reports, policy guide hand notes, different papers of JBL, prospectus of JBL, different text books and published books.

\section{Data Analysis:}

The data needed for conducting the study has been collected from the primary sources as well as secondary sources. In collecting the necessary data, care has been taken so that all the variables can comply with the objectives of the study. Data has been analyzed to find out the required information. 5 point Likert scale, necessary number of tables, charts, and graphs were used. Ms-Word, Excel or any required computer program are used to process the data. Necessary tables have been prepared on the basis of collected primary data and various techniques have been applied to analyses on the basis of classified information.

\section{Literature Review}

Job satisfaction provides ample benefits to the organization. Human|Workforce is prime need of the organization. Without sufficientlproper workforce productivity and profitability will not boost up which is core objectives of the organization. All the above said objectives can be attainable only when workforce of the organization is satisfied. There were many hurdles came in providing the maximum satisfaction to employees. To overcome the problems time to time many studies have been conducted for presenting the picture of job satisfaction. The reviews of these research in relation to Bangladesh as well as abroad are given below. International Journal of New Innovations in Engineering and Technology (IJNIET) Vol. 1 Issue 3 February 201342 ISSN: 2319-6319 Dutta, S. (1959) conducted research from two districts in Haryana a survey of 200 employees noticed that, remuneration in form of money was less important than security at work place and the advancement for older and married employees were more important. Clark, Andrew E. (1995) tested the hypothesis that utility depends on income relative to a 'comparison' or reference level. The study was done on 5,000 British workers showed that the satisfaction levels of the workers were negatively related to their earnings levels. Secondly, it is established that, holding income constant, satisfaction was nosedived for the lever of education. He felt that it could be due to the fact that education induces higher aspirations. Barnes (1998) conducted research of job satisfaction among rehabilitation physicians, occupational therapy specialists, and speech pathologists. It had been recommended that three factors that describe job satisfaction: External context factors and internal context factors, as well as internal content factors. External factors that affect job satisfaction comprise a competitive salary and additional rewards such as release from work due to family matters, flexible work schedule, and child raising support. The stated internal context factors were "less substantial but inherent to work". These could be factors that are controlled by external forces and directly affect internal employee satisfaction, such as adequate working hours and workload, stable working environment, and support of administration. Barnes also pointed out internal content factors that, first of all, are controlled by the professional himself/herself and that may affect employee's competence and feeling of effectiveness in the organization. The author concludes that A study by Slevaraj (2009) states; private banks were more successful then public sector in terms of implementing Total Quality Management (TQM) initiatives, in context of HR, customer focus, and top management commitment. Public sector banks structure compensation in a way such that there are lower pay differentials between the employees, long-term tenure is rewarded and there is a high base pay, whereas in the private sector banks, there are larger pay differentials, fewer rewards for tenure, and pay for performance (D'Souza, 2002). However, private sector banks do not provide job security and would lay off their employees in cases of poor performance or adverse market conditions (Jha, Gupta \&Yadav, 2008). 
Internal factors have more influence on employee career satisfaction than external. Maslow (1954) suggested that human needs form a five-level hierarchy ranging from physiological needs, safety, belongingness and love, esteem to self-actualization. Based on Maslow's theory, job satisfaction has been approached by some researchers from the perspective of need fulfilment (Kuhlen, 1963; Wood, 1970; Conrad et al., 1985). Herzberg et al. (1959) formulated the two-factor theory of job satisfaction and postulated that satisfaction and Dissatisfaction were two separate and sometimes even unrelated phenomena. Intrinsic factors named 'motivators' (that is, factors intrinsic to the nature and experience of doing work) were found to be job 'satisfiers' and included achievement, recognition, work itself and responsibility. Extrinsic factors which they named 'hygiene' factors were found to be job 'dissatisfies' and included company policy, administration, supervision, salary, interpersonal relations and working conditions. Herzberg and Mausner's MotivationHygiene theory has dominated the study of the nature of job satisfaction, and formed a basis for the development of job satisfaction assessment (Table 1).Thus job satisfaction is the affective orientation that an employee has towards his or her work (Price, 2001).

\section{Job Satisfaction Scenario Of Janata Bank Limited}

Analysis based on 5 point Likert scale: To find out the level of job satisfaction under the topic "An analysis on Job Satisfaction of Employees of Govt. Banks: A Study on Janata Bank Limited" a direct survey was conducted to the eight (8) various branches of JBL. Data were collected through structured questionnaire which carries 15 topic related questions. 5 point Likert scale was used to find out the result. In this method every question carries 5 options and each options carries specific point given below:

\begin{tabular}{|l|c|}
\hline Option & Value \\
\hline Highly satisfied/Very good & 5 \\
\hline Satisfied/Good & 4 \\
\hline Moderately satisfied/Average & 3 \\
\hline Dissatisfied/Bad & 2 \\
\hline Highly Dissatisfied/Very bad & 1 \\
\hline
\end{tabular}

Total 60 respondents were asked for the answer. After getting the data the total point of each question was calculated on the basis of respondents' answer then total point was divided by the number of total respondents to get the final level of satisfaction on the heading of one question. Table 01 shows an observation about working environment

\begin{tabular}{|c|c|}
\hline Criteria & Likert point \\
\hline Working Environment & 3.4 \\
\hline
\end{tabular}

Table 01: Observation about working environment

A congenial working environment is must for best output. Janata Bank Limited has average level of satisfaction in case of working environment. Satisfaction rating is 3.4 out of 5; it indicates that the satisfaction level about working environment is nearly good. Table 02 and Figure 01 show an observation about satisfaction level about workload and stress.

\begin{tabular}{|c|c|}
\hline Criteria & Likert point \\
\hline Workload and Stress & 4.07 \\
\hline
\end{tabular}

Table 02: Observation about satisfaction level about workload and stress.

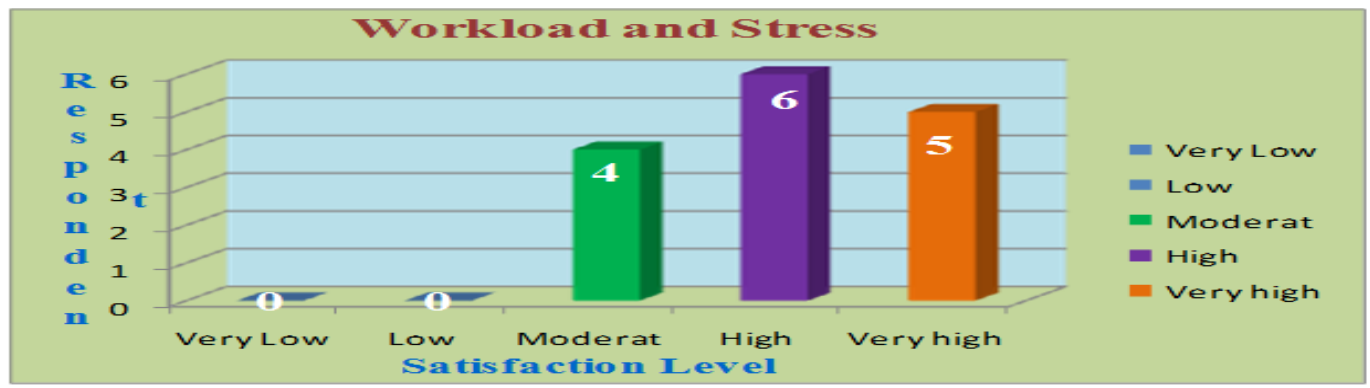

Figure 01: Job satisfaction about workload and stress (Source: Primary data)

It is apparent from the figure 01, the workload and stress level in Janata Bank Limited is very high. Among 60 employees of Janata Bank Limited 16 respondents put their opinion about moderate level stress and workload, 24 respondents gave opinions about high workload and stress and rest of 20 respondents said that 
they have very high pressure and work load. By analyzing the data in 5 point Likert scale Table 2 , shows the 4.07 Likert point which denotes the high pressure of the respondent in case of workload and stress. Table 03 shows an observation about satisfaction level with the nature of work. Average level of satisfaction about nature of work exists among the employee. Table 04 shows an observation about compensation package

\begin{tabular}{|c|c|}
\hline Criteria & Likert point \\
\hline Nature of work & 3.13 \\
\hline
\end{tabular}

Table 03: Observation about satisfaction level with the nature of work

The compensation package in Janata Bank Limited is not good enough. Satisfaction level of employee is average level and it is not also nearly good. Table 05 and Figure 02 show the satisfaction level with Compensation package.

\begin{tabular}{|c|c|}
\hline Criteria & Likert point \\
\hline Compensation package & 3.13 \\
\hline
\end{tabular}

Table 04: Observation about compensation package

\begin{tabular}{|c|c|}
\hline Criteria & Likert point \\
\hline Satisfaction about Compensation & 3.07 \\
\hline
\end{tabular}

Table 05: Satisfaction level with Compensation package.

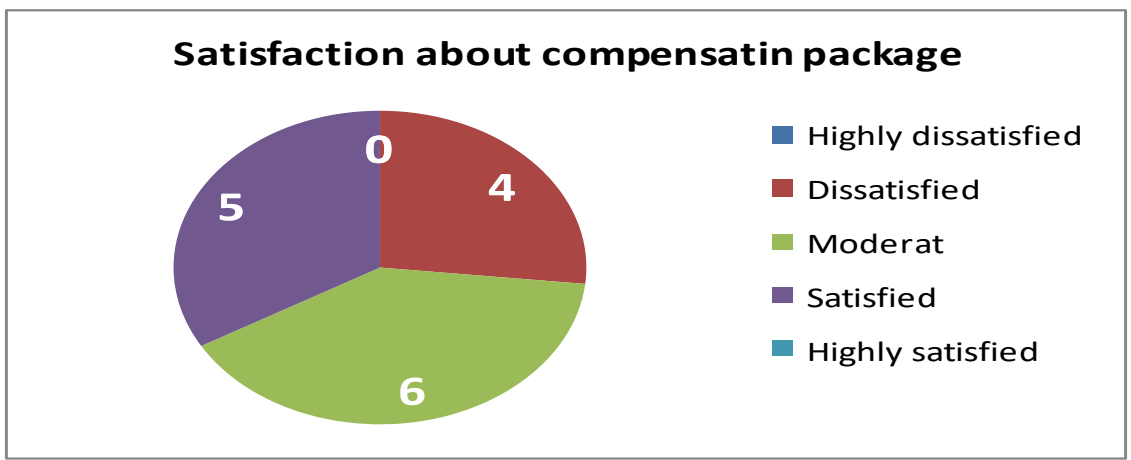

Figure 02: Job satisfaction with Compensation package (Source: Primary data)

The pie chart shows the satisfaction level with compensation package, it is very clear from the figure 02; the Compensation package in Janata Bank Limited is average level. Among 60 respondents of Janata Bank Limited 16 respondents showed their dissatisfaction about compensation, 24 respondents gave opinions about moderate level of satisfaction and rest of 20 respondents said that they are satisfied with compensation package. By analyzing the data in 5 point Likert scale Table 05, shows the 3.07 Likert point which indicates the average level of satisfaction among the employees. Table 06 and Figure 03 show an observation about Allowances and others incentive.

\begin{tabular}{|l|l|}
\hline Criteria & Likert point \\
\hline Allowances and others Incentive & 3.0 \\
\hline
\end{tabular}

Table 06: Observation about Allowances and others incentive

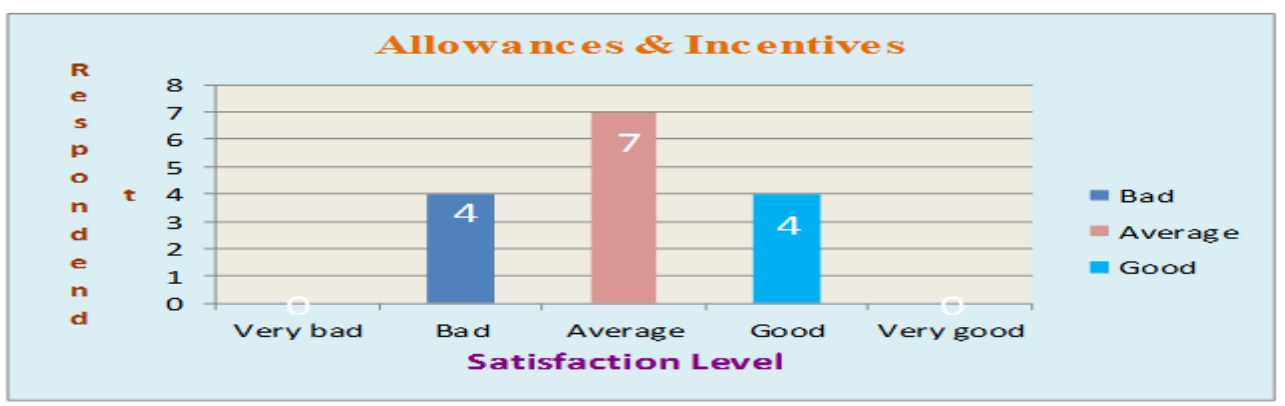

Figure 03: Job satisfaction with Allowances and others incentive (Source: Primary data) 
The bar chart shows the satisfaction level with Allowances and others Incentive. It is very apparent from the figure 03, the Allowances and others Incentive in Janata Bank Limited is average level. Among 60 respondents of Janata Bank Limited 16 respondents put their opinion as bad allowances, 28 respondents gave opinions about average level of satisfaction and rest of 16 respondents said that they have good allowances and incentives. By analyzing the primary data in 5 point Likert scale Table 6 , shows the 3.0 Likert point which indicates the average level of satisfaction among the employees about allowances and other incentives. Table 07 shows the satisfaction level with future pecuniary benefits. Table 08 shows an observation about transportation and accommodation facilities.

\begin{tabular}{|c|c|}
\hline Criteria & Likert point \\
\hline Pecuniary benefits & 2.73 \\
\hline
\end{tabular}

Table 07: The satisfaction level with future pecuniary benefits.

\begin{tabular}{|c|c|}
\hline Criteria & Likert point \\
\hline Transportation and Accommodation & 1.80 \\
\hline
\end{tabular}

Table 08: Observation about transportation and accommodation facilities

There is hardly scope of Transportation and Accommodation for the staff of Janata Bank Limited. Most of the employees do not get any transportation or any accommodation facilities provided by the Bank. Table 09 shows an observation about employee participation in decision making process

\begin{tabular}{|l|l|}
\hline Criteria & Likert point \\
\hline Employee participation & 2.80 \\
\hline
\end{tabular}

Table 09: Observation about employee participation in decision making process

There is scarcely participation of employees in Decision making about the organization and others major decision. In these criteria the satisfaction level is 2.80 which denote the lower participation of employees. Table 10 and Figure 04 show an observation about Training facilities.

\begin{tabular}{|l|l|}
\hline Criteria & Likert point \\
\hline Training facilities & 3.87 \\
\hline
\end{tabular}

Table 10: Observation about Training facilities

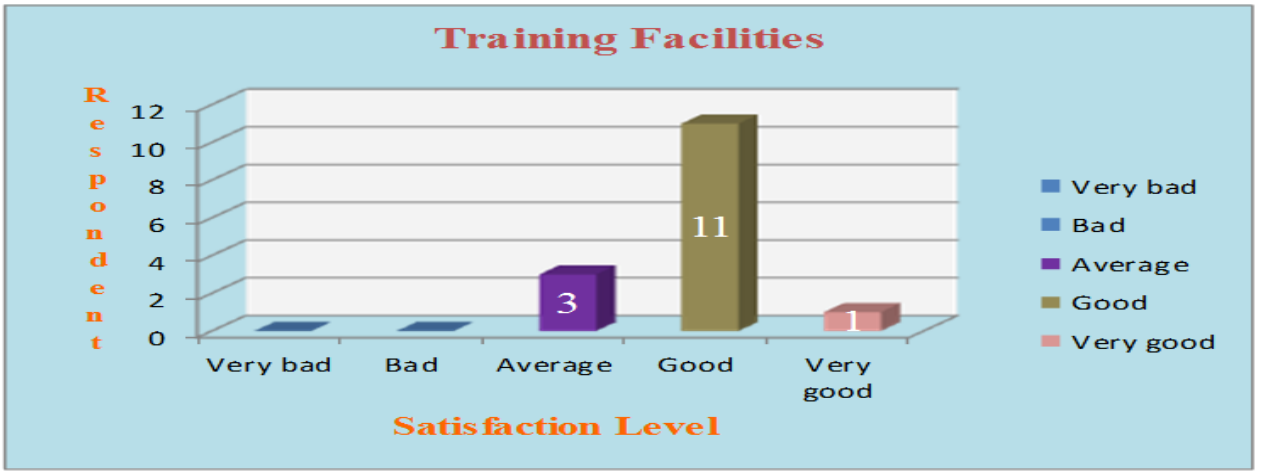

Figure 04: Job satisfaction about Training facilities (Source: Primary data)

The chart shows the satisfaction level about Training facilities. It is apparent from the figure 04, at present the training facilities and programs of Janata Bank Limited is affordable, and it is nearly good. Among 60 respondents 12 showed their average level of satisfaction, 44 respondents said that it is good and rest of 4 respondents said that the Training facilities is very good. In 5 point Likert scale Table 10, shows the 3.87 Likert point which indicates the average level of satisfaction among the employees about Training facilities and it is also good. Table 11 shows an observation about promotion system.

\begin{tabular}{|c|c|}
\hline Criteria & Likert point \\
\hline Promotion system & 3.53 \\
\hline
\end{tabular}

Table 11: Shows an observation about promotion system 
It is apparent from table 11 that promotion system of Janata Bank Limited is affordable, and it is nearly good. Among 60 respondents 4 employees showed low level of satisfaction, 20 respondents said that it is moderate level and rest of 36 respondents said that the promotion system is good.5 point Likert scale Table 11, is showing the 3.53 Likert point which indicates the average level of satisfaction among the employees about promotion system..

\begin{tabular}{|c|c|}
\hline Criteria & Likert point \\
\hline Relationship with superior & 3.60 \\
\hline
\end{tabular}

Table 12: Observation about Relationship with superior

The table shows the satisfaction level about Relationship with superior. It is very apparent from the table that the level of relationship between employee and superior is not bad it is moderately good. In primary survey, among 60 respondents, 5 respondents showed dissatisfaction about it, 20 respondents gave opinion about moderate level of satisfaction and rest of 35 respondents said that they have good and satisfactory level of relationship with the superior. Relationship with superior is an important factor to get more output from employees. It is very essential to motivate employees to be dedicated to the work. The satisfaction level of employees about Relationship with superior is nearly good. Table 13 shows the satisfaction level with Job security.

\begin{tabular}{|c|c|}
\hline Criteria & Likert point \\
\hline Job security & 4.40 \\
\hline
\end{tabular}

Table 13: Satisfaction level with Job security

Job security is the most influential factors for the employees in Bangladesh. Job security of government organization is very high. Most of the respondent of Janata Bank Limited is quite satisfied about job security ant they put their opinion positively. In primary survey, among 60 respondents, 8 respondents showed moderate satisfaction about it, 20 respondents gave opinion about good level of satisfaction and rest of 32 respondents said that they are highly satisfied and they have very good Job security. Likert point 4.40 denotes the very good level of satisfaction about Job security. Table 14 shows the satisfaction level with employee supervision of superior.

\begin{tabular}{|c|c|}
\hline Criteria & Likert point \\
\hline Employee supervision & 3.47 \\
\hline
\end{tabular}

Table 14: Satisfaction level with employee supervision of superior

Employee supervision is an important factor to get more output from employees. It is very necessary to influence employees to be devoted to the work. The satisfaction level of employees about Employee supervision is nearly good.

\begin{tabular}{|l|l|}
\hline Criteria & Likert point \\
\hline Performance appraisal system & 2.67 \\
\hline
\end{tabular}

Table 15: Satisfaction level about performance appraisal system

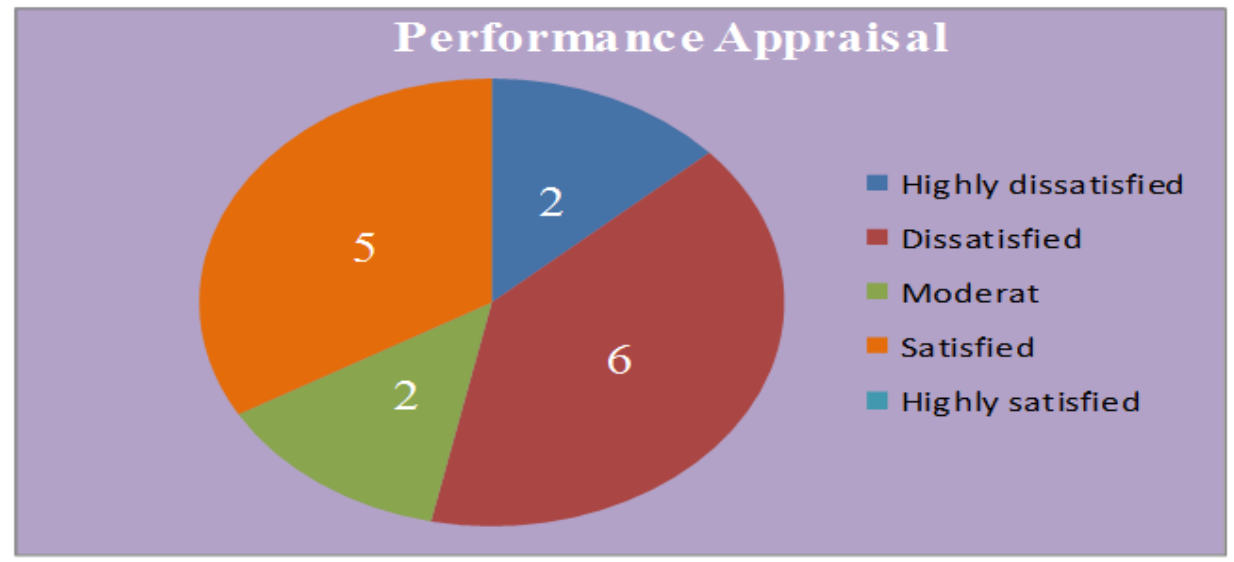

Figure 05: Job satisfaction about Performance appraisal system (Source: Primary data) 
It is very essential to have good and sound performance appraisal system in any organization but in Janata Bank Limited performance appraisal system is not reliable. The pie chart shows the satisfaction level about performance appraisal system. It is very apparent from the figure 11; the level of Performance appraisal system is below average level. In field survey, among 60 respondents, 8 respondents are highly dissatisfied about it, 24 respondents are also dissatisfied, 8 respondents are moderately satisfied and rest of 20 respondents said that they are satisfied with current Performance appraisal system. Respondents are somewhat dissatisfied about Performance appraisal system and the point is only 2.87 which indicate the lower condition.

Total Average Table: It shows the average of 15 tables of Likert points as follows-

\begin{tabular}{|l|l|}
\hline Total Likert points of 15 tables & Average Likert points \\
\hline 48.67 & 3.25 \\
\hline
\end{tabular}

Considering all the factors, Total Likert table analysis shows the average satisfaction level about all the factors. The Average Likert point is 3.25 which is above from the average point 3 of Likert scale. Satisfaction about some criteria is below average and some is moderate and rest of the criteria is good. So, there is a good and satisfactory level existing among the employees of Janata Bank Limited. Job Satisfaction is moderately good.

\section{Major Findings Of The Study}

Following things is found from analysis:

1. Workload and working stress is very high at Janata Bank Limited but their compensation package is not satisfactory enough to meet the demand of the employees.

2. Loan facilities of employees in Janata Bank Limited are good but allowance and other incentives are average for the employees.

3. Employees have no transportation and accommodation facilities.

4. There has good opportunity for the employee training and low performance appraisal system at branch level in Janata Bank Limited.

5. Promotion system is moderate, Job security level and after retirement plan is very good in Janata Bank Limited.

6. The internal environment of Janata Bank Limited is visually not attractive \& comfortable. Employees are not totally satisfied with it.

7. Employees are friendly about customer service in Janata Bank Limited.

\section{Recommendations}

As job Satisfaction is a key point to acquire the strategic goal of organization, the management should be more serious to ensure some tactics that can be effective for gratifying the workers. In recent times, the successful managers deal with their workers using different tools and techniques to satisfy their needs. In this section, some well-designed tools and tactics are recommended as follows:

1. The pay structure must be changed for the employees to keep them motivated;

2. The intrinsic parts of the job should be focused;

3. Cognitive dissonance should be reduced;

4. Work Safety and a friendly work environment must be maintained;

5. Promotion must be given on due time with the advancement opportunities of career growth;

6. Regular supervision must be done;

7. Training opportunities for employees must be enhanced;

8. Employees must be valued andparticipation of the workers in decision-making must be ensured and also they should be encouraged for group work and work team and remove workers' conflict.

\section{Conclusion}

Job Satisfaction can be influenced by a variety of factors, e.g. the quality of one's relationship with their supervisor, the quality of the physical environment in which they work, degree of fulfilment in their work, etc. Numerous research results show that there are many factors affecting the job Satisfaction. There are particular demographic traits (age, education level, tenure, position, marital status, years in service, and hours worked per week) of employees that significantly affect their job Satisfaction. Motivating factors are achievement, recognition, the job conducted, responsibility, promotion and the factors related to the job itself for personal development. Motivating factors in the working environment result in the job Satisfaction of the person while protective ones dissatisfy him/her. Maslow connects the creation of the existence of people's sense of Satisfaction with the maintenance of the classified needs. These are: physiological needs (eating, drinking, resting, etc.), security needs (pension, health insurance, etc.), the need to love (good relations with the 
environment, friendship, fellowship, to love and to be loved), need to self-esteem (self-confidence, recognition, adoration, to be given importance, status, etc.) need of self-actualization (maximization of the latent [potential] power and capacity, development of abilities, etc.) Insufficient education, inability to select qualified workers for the job, lack of communications, lack of job definitions, all affect job Satisfaction negatively. It has been asserted that participating in the management, having the decision making power, independence on the job and the unit where the individual works, have positive impact upon the job Satisfaction. The job itself (the work conducted), and achievement and recognition at work result in Satisfaction while the management policy, relations with the managers and colleagues result in dissatisfaction. Factors related to the job itself such as using talents, creativity, responsibility, recognition have influence on the job Satisfaction.

\section{References}

[1] Barnes, L.L.B., Agago, M.O.,Coombs, W.T. (1998). Effects of job related stress on faculty intention to leave, Academia Research in Higher Education. 39, 457-469.

[2] Berry, L. (1981). The Employee as customers, Journal of Retail Banking,12, 33-44

[3] Conrad, K.M., Conrad, K.J., and Parker, J.E.(1985). Job satisfaction among occupational health nurses, Journal of Community Health Nursing. 2, 161-173

[4] Clark, A.E., \& Oswald, A.J.(1996). Satisfaction and comparison income, Journal of Public Economics. 61, 359-381

[5] Cheung, C. K., \& Scherling, S. A. (1999).Job Satisfaction, Work Values, and Sex Differences in Taiwan's Organizations, The Journal of Psychology, (Taiwan) 133 (5),563-575

[6] Dutta, S. (1959), International Journal of New Innovations in Engineering and Technology (IJNIET). 1(3)

[7] De Souza, R. (2002). Walking upright here: Countering prevailing discourses through reflexivity and methodological pluralism. (Unpublished MA (Nursing) Thesis), Massey University, Albany, NZ.

[8] Ganguli, H. C. (1994), Job Satisfaction Scales for Effective Management: Manual for Managers and Social Scientists, New Delhi: Concept Publishing Company, 344-346

[9] Hemple, G.H., \& Simonson, D.G. (1998). Bank Management: Text \& Cases. (8th edition), New York.

[10] Herzberg, F., Mausner, B., Snyderman, B. (1959), The motivation to work. (2nd edition), Newyork: John Wiley and Sons

[11] Jha, B.K.,Gupta, S.L., Yadav, P. (2008). Use and effectiveness of new technologies in Indian banking a study, The ICFAI Journal of Service Marketing. 6(1), 6-22

[12] Khan, A. R. (2008), Bank Management a Fund Emphasis. (1 ${ }^{\text {st }}$ edition). Dhaka: Brother's publication.

[13] Kuhlen, R.G.(1963). Needs, perceived need satisfaction opportunities, and satisfaction with occupation, Journal of Applied psychology. XLVII, 56-64

[14] Locke, E. (1976). The Nature and Causes of Job Satisfaction", in Handbook of Industrial/ Organizational Psychology Edited by M.D. Dunnette (Chicago: Rand McNally, 1976): 901-969.

[15] Maslow, A. (1954). Motivation and Personality, New York: Harper \& Row.

[16] Price, J.L., \& Mueller, C.W.(1981). A causal model of turnover for nurses, Journal of Academic Management. 24, 543-565

[17] Smith, P. C., Kendal, L. M., Hulin, C. L. (1969). The Measurement of Satisfaction in Work and Retirement” in: Huang, H. J., (1999) Job Rotation from the Employees' Point of View, Research \& Practice in Human Resource Management, $7(1), 76$

[18] Selvaraj, M. (2009). Total quality management in Indian commercial Banks: A comparative study, Journal of Marketing and Communication. 4(3), 59-70

[19] Wood, D., \& Le Bold, W., (1970).The multivariate nature of professional job satisfaction, Personal Psychology. 23(2), 173-189

[20] Others Annual Report of Janata Bank Limited' 2013 and 2014 WWW: www.janatabank-bd.com 